\title{
Chromium(III) Glycinate Complex Supplementation Improves the Blood Glucose Level and Attenuates the Tissular Copper to Zinc Ratio in Rats with Mild Hyperglycaemia
}

\author{
Ewelina Król ${ }^{1}$ (D) $\cdot$ Zbigniew Krejpcio $^{1} \cdot$ Monika Okulicz $^{2} \cdot$ Hanna Śmigielska $^{3}$ \\ Received: 7 January 2019 / Accepted: 20 February 2019/Published online: 2 March 2019 \\ (C) The Author(s) 2019
}

\begin{abstract}
The aim of the study was to evaluate the hypoglycaemic potential of supplementary $\mathrm{Cr}$ in the form of chromium(III) glycinate (CrGly) in the diabetic model of rats. The experiment was conducted on 40 male Wistar rats, of which 30 were made diabetic by injection of a single dose of streptozotocin $(55 \mathrm{mg} / \mathrm{kg} \mathrm{b.m.),} \mathrm{while} \mathrm{the} \mathrm{remaining} 10$ rats served as the healthy control. After inducing hyperglycaemia, 2 groups of diabetic rats (10 rats each) were supplemented with $\mathrm{Cr}$ either as CrGly or chromium(III) picolinate (CrPic) given orally at a dose of $10 \mathrm{mg} / \mathrm{kg}$ diet (about $0.75 \mathrm{mg} \mathrm{Cr} / \mathrm{kg} \mathrm{b.m.)} \mathrm{with} \mathrm{adequate} \mathrm{AIN-93M} \mathrm{diet} \mathrm{for} 7$ weeks. At the termination of experiment, all animals were sacrificed to collect blood and internal organs for biochemical assays. Blood biochemical indices and tissular trace element contents $(\mathrm{Fe}, \mathrm{Zn}, \mathrm{Cu}, \mathrm{Cr}$ ) were measured and compared with the values of the untreated groups. It was found that CrGly significantly decreased blood glucose, total cholesterol, HDL cholesterol and triacylglycerol levels more efficiently than CrPic. Furthermore, both $\mathrm{Cr}$ compounds normalized disturbed the serum, renal and cardiac molar $\mathrm{Cu} / \mathrm{Zn}$ ratio, as well as restored the kidney $\mathrm{Zn}$ and $\mathrm{Cu}$ levels in rats with hyperglycaemia. Supplementary $\mathrm{Cr}$ did not increase the tissular $\mathrm{Cr}$ levels in diabetic rats. The study confirmed the hypoglycaemic potential of CrGly in the diabetic model of rats.
\end{abstract}

Keywords Chromium(III) glycinate complex $\cdot$ Chromium(III) picolinate $\cdot$ Supplementation $\cdot$ Hyperglycaemia $\cdot$ Diabetic rats

\section{Introduction}

Diabetes is a metabolic disease causing glucose homeostasis disorders. It progresses over time. According to the WHO estimates, in 2014, there were 422 million people aged over 18 years with diabetes worldwide [1]. Therefore, dietary supplements that could improve disturbed carbohydrates balance are very popular, especially in the USA. Recently, the analysis of the NHANES study data and the filtering the database for the required covariates (sex, ethnicity, socioeconomic status,

Ewelina Król

ewelina.krol@up.poznan.pl

1 Insitute of Human Nutrition and Dietetics, Poznań University of Life Sciences, ul. Wojska Polskiego 31, 60-624 Poznan, Poland

2 Department of Animal Physiology and Biochemistry, Poznań University of Life Sciences, ul. Wołyńska 31, 60-624 Poznan, Poland

3 Department of Natural Science and Quality Assurance, Poznań University of Economics and Business, al. Niepodległości 10, 61-875 Poznan, Poland body mass index, diabetes diagnosis, supplement usage and laboratory $\mathrm{HbA1c}$ values) showed that $58.3 \%$ of adults had consumed a dietary supplement in the previous month. Among them, $28.8 \%$ reported consuming a dietary supplement that contained chromium. The authors concluded that the odds ratio of the incidence of type 2 diabetes in the people who consumed chromium-containing supplements within the previous 30 days was lower than in nonusers [2].

Dietary Cr(III) supplementation is generally considered as safe, but in some cases, it may lead to the accumulation of this element in the kidneys [3]. Therefore, $\mathrm{Cr}$ (III) supplementation is not recommended for people with kidney or liver disease. Moreover, high doses of $\mathrm{Cr}$ (III) supplements affect the homeostasis of other elements.

Although the use of chromium(III) supplements in diabetes management is controversial, researchers are still looking for factors that could influence its efficacy. The most popular form of $\mathrm{Cr}$ (III) on dietary supplements market are picolinate, brewer's yeast enriched with chromium, niacin-bound $\mathrm{Cr}$ (III) and chloride. Generally, the efficiency of $\mathrm{Cr}$ (III) supplementation depends on the bioavailability of $\mathrm{Cr}(\mathrm{III})$, which is still very low ranging from 
$0.5 \%$ (chromium (III) chloride) to $10 \%$ (brewer's yeast) [4]. Recently, these results were verified in rats and on humans [5]. The authors found that among the $\mathrm{Cr}$ (III) supplements user analysis (Cr-picolinate, Cr-nicotinate, Cr-phenylalaninate, $\mathrm{Cr}$-proprionate, or $\mathrm{Cr}$-chloride), 7 days after oral administration of ${ }^{51} \mathrm{Cr}$ to rats the apparent absorption was low, ranging from 0.04 to $0.24 \%$. These values were higher in three volunteers who took $400 \mu \mathrm{g}$ $\mathrm{Cr}$, where the highest value $(0.95 \%)$ was observed for $\mathrm{Cr}(\mathrm{D}-\mathrm{Phen})_{3}$.

The problem of low bioavailability of chromium could be solved by finding non-toxic ligands facilitating its absorption in animal and humans. In the last decade, many amino acid ligands have been synthetized and tested, e.g. propionate, malate, acetate, histidinate, D-phenylalanine, glycinate and methionine [6-11].

Earlier studies showed that the trinuclear oxo-centered $\mathrm{Cr}$ carboxylate structure (as in the chromium(III)-glycine complex) was a key element that determined high bioavailability and biological activity of the $\mathrm{Cr}$ (III) compound. In contrast to chromium(III) picolinate (CrPic), CrGly is well soluble in water $[12,13]$.

In an earlier study, the effect of synthetic $\mathrm{Cr}$ (III) complexes (acetate, chloride, glycinate, histidinate, lactate and propionate) on insulin binding and signal transduction was investigated in vitro on three experimental models: isolated rat liver membranes and cultured mouse $\mathrm{C} 2 \mathrm{C} 12$ myoblasts and 3T3L1 preadipocytes [14]. In the absence of insulin, two $\mathrm{Cr}$ (III) complexes, i.e. chromium glycinate (CrGly) and acetate ( $\mathrm{CrAc})$, slightly elevated the phosphorylation at tyrosine IRS-1. This suggested that in vivo these complexes might significantly enhance inulin signaling inside cells, especially at low levels of insulin in the blood.

The aim of this study was to evaluate the hypoglycaemic potential of the supplementary $\mathrm{Cr}$ (III) glycinate (CrGly) complex in comparison with $\mathrm{Cr}(\mathrm{III})$ picolinate in mild diabetic model of rats.

\section{Material and Methods}

\section{Animals}

Male Wistar rats $(n=40,6$ weeks old, mean initial body weight $175 \mathrm{~g}$ ) were purchased from the Licensed Laboratory Animals Breeding Center at the Poznań University of Medical Sciences (Poznań, Poland). Throughout the experiment, the rats were kept at animal care facility under controlled temperature $\left(21 \pm 2{ }^{\circ} \mathrm{C}\right)$ and humidity $(55-60 \%)$ with artificial $12 \mathrm{~h} /$ $12 \mathrm{~h}$ day/night cycle. After 7 days of adaptation, the animals were divided into four groups: $\mathrm{C}$ - the control group, D - the diabetic control group, $\mathrm{D}+\mathrm{CrGly}$ - diabetic rats fed a diet supplemented with CrGly at the dose of $10 \mathrm{mg} \mathrm{Cr} / \mathrm{kg} /$ diet and D+ CrPic-diabetic rats fed a diet supplemented with chromium(III) picolinate at a dose of $10 \mathrm{mg} \mathrm{Cr} / \mathrm{kg} /$ diet.

\section{Diets}

For 7 weeks, the rats were fed semi-synthetic diets composed according to the American Institute of Nutrition (AIN-93M) recommendations [15]. The diets consisted of casein (14\%), soybean oil (4\%), wheat starch $(62.32 \%)$, sucrose (10\%), potato starch (5\%), L-cysteine $(0.3 \%)$, vitamin mix AIN-93M (1\%) and mineral mix AIN-93M (3.5\%). Two mineral mixtures were enriched with either CrGly or $\mathrm{CrPic}$ to a level of $10 \mathrm{mg}$ elemental $\mathrm{Cr} / \mathrm{kg}$ diet. The chemical composition of the experimental diets is shown in Table 1. During the entire experimental period, the animals had free access to food and distilled water. The food intake was monitored daily. The body mass gain was monitored weekly.

\section{Induction of Diabetes}

After the acclimatisation period, the rats were intraperitoneally injected with STZ $(55 \mathrm{mg} / \mathrm{kg}$ body mass in citric buffer, $\mathrm{pH}=$ 4.4, Sigma-Aldrich (Saint Louis, MO, USA)) to induce
Table 1 The chemical composition of diets used in experiment

\begin{tabular}{|c|c|c|c|c|}
\hline \multirow[t]{2}{*}{ Ingredient } & \multicolumn{4}{|c|}{ Experimental diets } \\
\hline & $\mathrm{C}$ & $\mathrm{D}$ & D+CrGly & $\mathrm{D}+\mathrm{CrPic}$ \\
\hline Protein & $12.93 \pm 0.07$ & $12.68 \pm 0.38$ & $12.75 \pm 0.05$ & $12.21 \pm 0.32$ \\
\hline Fat & $4.92 \pm 0.04$ & $4.80 \pm 0.10$ & $4.96 \pm 0.04$ & $4.86 \pm 0.18$ \\
\hline Carbohydrates & $70.65 \pm 0.09$ & $71.10 \pm 0.04$ & $70.78 \pm 0.07$ & $71.77 \pm 0.26$ \\
\hline Ash (\%) & $2.92 \pm 0.16$ & $2.81 \pm 0.17$ & $2.64 \pm 0.21$ & $2.75 \pm 0.04$ \\
\hline $\mathrm{Fe}(\mathrm{mg} / \mathrm{kg})$ & $48.65 \pm 4.38$ & $46.54 \pm 5.81$ & $47.19 \pm 3.70$ & $49.45 \pm 3.21$ \\
\hline $\mathrm{Zn}(\mathrm{mg} / \mathrm{kg})$ & $37.56 \pm 4.56$ & $38.99 \pm 2.45$ & $37.77 \pm 4.76$ & $39.76 \pm 6.34$ \\
\hline $\mathrm{Cu}(\mathrm{mg} / \mathrm{kg})$ & $6.54 \pm 2.34$ & $6.43 \pm 3.48$ & $5.99 \pm 1.23$ & $6.11 \pm 1.41$ \\
\hline $\mathrm{Cr}^{*}(\mathrm{mg} / \mathrm{kg})$ & $1.34 \pm 0.32$ & $1.44 \pm 0.24$ & $11.75 \pm 0.45$ & $11.90 \pm 0.53$ \\
\hline
\end{tabular}

*Cr(III) was added to mineral mix in the forms as follows: D+CrGly-chromium(III) glycinate; D+CrPicchromium(III) picolinate 
hyperglycaemia and diabetes. The rats from the control group were injected only with the carrier (citric buffer, $\mathrm{pH} 4.4$ ). Three days after the injection, blood drops were taken from the tail vein and placed on test strips to measure the blood glucose concentration (Optium Medisense glucometer, Abbott Co., USA). After the injection of STZ, all the animals exhibited elevated fasting blood glucose levels ( $>9 \mathrm{mmol} / \mathrm{l})$ and were classified and named as "mild diabetic" (D).

\section{Test Chemicals}

Chromium(III) complex with glycine (CrGly) in the form of nitrate salt (chemical formula $\left[\mathrm{Cr}_{3} \mathrm{O}\left(\mathrm{NH}_{2} \mathrm{CH}_{2} \mathrm{CO}_{2}\right)_{6}\left(\mathrm{H}_{2} \mathrm{O}\right)_{3}\right]+$ $\mathrm{NO}_{3} \cdot \mathrm{H}_{2} \mathrm{O}$, the content of $\mathrm{Cr} 25.7 \%$ ), as an analogue of chromium(III) propionate complex $(\mathrm{Cr} 3$, chemical formula $\left.\left[\mathrm{Cr}_{3} \mathrm{O}\left(\mathrm{O}_{2} \mathrm{CCH}_{2} \mathrm{CH}_{3}\right)_{6}\left(\mathrm{H}_{2} \mathrm{O}\right) 3\right]^{+} \mathrm{NO}_{3}\right)$ was synthesized in the laboratory of the Department of Product Ecology, Poznan University of Economics and Business, according to the method described previously [16].

Chromium(III) picolinate (CrPic) (Nutrition 21, Inc. NY, USA) was kindly provided by Professor Kazim Sahin from Firat University (Elazig, Turkey).

The content of elemental $\mathrm{Cr}$ in the compounds was determined by the AAS method (spectrometer AAS-3 with BC correction, Zeiss, Germany).

\section{Data Collection}

After $16 \mathrm{~h}$ fasting, the rats were anesthesized with an intraperitoneal thiopental injection $(40 \mathrm{mg} / \mathrm{kg} \mathrm{b.m}$.) and dissected to collect blood from the aorta. The inner organs (liver, kidneys, heart, spleen, pancreas, testes) were removed. Their blood was collected into test tubes containing EDTA. Next, it was centrifuged $\left(3500 \times \mathrm{g}\right.$ for $\left.10 \mathrm{~min}, 4{ }^{\circ} \mathrm{C}\right)$ and stored at $-20^{\circ} \mathrm{C}$ for biochemical tests.

Internal organs and tissues were washed in saline, weighed and stored at $-20^{\circ} \mathrm{C}$ until analysis. All the procedures applied in this study were accepted by the Animal Bioethics Committee of Poznań, Poland (Approval no. 47/2010).

\section{Laboratory Analyses}

\section{Blood Biochemistry}

The blood serum indices were measured with standard methods using an Olympus AU 560 analyser (Tokyo, Japan). In particular, the serum glucose level was measured with the hexokinase method [17]. The serum total, LDL, HDL cholesterol and triacylglycerol concentrations were measured with colorimetric methods [18-20]. The insulin concentration was determined with the RIA method using a rat-specific kit (RI-13K, Millipore Corporation, St. Charles, MO, USA). The serum GST, TBARS and C-reactive protein concentrations were measured with rat-specific kits (Cayman Chemical; 1180 East Ellsworth Road, Ann Arbor, Michigan, USA; Wuhan EIAab Science Co., Biopark, Optics Valley, Wuhan, China).

The ALT and AST enzyme activities were measured with the kinetic methods. The urea concentration was determined by the kinetic method using urease and glutamine dehydrogenase. The total protein concentration was measured with the colorimetric method, using $\mathrm{Cu}^{+2}$ ions. The creatinine concentration was measured with the Jaffe's kinetic method using picric acid [21-23].

Insulin resistance was characterized with the homeostasis model assessment (HOMA) indices adjusted to the rodent model $[24,25]$.

HOMA-IR $=($ Fasting Glucose $[\mathrm{mmol} / \mathrm{L}] \times$ Fasting Insulin $[\mathrm{mIU} / \mathrm{L}]) / 22.5$

\section{Microelements Determination}

The rats' tissues were digested in $65 \%(w / w)$ spectra pure $\mathrm{HNO}_{3}$ (Suprapur, Merck KGaA, Darmstadt, Germany) in the Microwave Digestion System (Mars-5, CEM Corp., Matthews NC, USA). Then, the concentrations of $\mathrm{Fe}, \mathrm{Zn}$ and $\mathrm{Cu}$ in the mineral solutions were measured with the $\mathrm{F}$ AAS method (AAS-3 spectrometer with BC, Zeiss, Germany). The content of $\mathrm{Cr}$ was measured with the graphite furnace AAS method (AA EA 5 spectrometer with BC, Jenoptic, Germany).

The accuracy of quantitative measurements of $\mathrm{Fe}, \mathrm{Zn}, \mathrm{Cu}$ and $\mathrm{Cr}$ was assured by simultaneous analysis of certified reference materials (bovine liver NIST ${ }^{\circledR}$ SRM $® 1577 \mathrm{c}$ and human serum HN2612 (Randox Laboratories, Crumlin, UK)). The mean recoveries of the reference material for tissues were as follows: $\mathrm{Fe}-98 \%, \mathrm{Zn}-95 \%, \mathrm{Cu}-102 \%, \mathrm{Cr}-103 \%$ and for the serum $\mathrm{Fe}-105 \%, \mathrm{Zn}-101 \%, \mathrm{Cu}-99 \%$.

The limit of detection (LOD) for the method of Cr determination was calculated by the equation LOD $=3 s / m(s-$ standard deviation of the measurements of the blank; $m$ - the slope of the calibration curve). Precision for the method was expressed as coefficient of variance (CV). These validation parameters were, respectively, $\mathrm{LOD}=0.32 \mu \mathrm{g} / \mathrm{L}$ and $\mathrm{CV}=$ $6.34 \%$.

\section{Statistical Analysis}

All the results were presented as means values \pm standard deviation. One-way analysis of variance (ANOVA) with post-hoc Tukey's test was used to determine statistically significant differences in the means values for each variable. The associations between variables were checked with the Pearson's correlation coefficient. The mean values were 
considered statistically different at $p<0.05$. The STATISTICA (ver. 10.0) program (StatSoft, Inc., Tulsa, USA) was used for all calculations.

\section{Results}

Table 2 shows the effects of chronic hyperglycaemia and supplementary $\mathrm{Cr}$ (III) compounds on overall nutritional indices in rats. Generally, hyperglycaemia induced by STZ injection (partial pancreatic cell damage) and inefficient glucose utilisation by cells brought about metabolic disorders. Food intake only slightly (insignificantly) increased $(p>0.05)$ to compensate for reduced energy availability; however, at the end of experiment, no statistically significant differences in body mass gain and body mass/body length ratio between all experimental groups were observed. Dietary $\mathrm{Cr}$ intake, as expected, was 7-8-fold higher in the $\mathrm{Cr}$ treated diabetic groups $(\mathrm{D}+\mathrm{CrGly}$ and $\mathrm{D}+\mathrm{CrPic})$ due to supplementation. Diabetic rats supplemented with CrGly consumed markedly less food by $12 \%$ on daily basis, as compared with diabetic control rats $(p<0.05)$. The feeding efficacy ratio (FER) as well as the absolute and relative internal organ masses were not statistically different among the experimental groups $(p>0.05)$.

Table 3 shows the effects of hyperglycaemia and supplementary $\mathrm{Cr}$ (III) compounds (CrGly and $\mathrm{CrPic}$ ) on the diabetic rats' glucolipid indices. A single STZ injection at a dose of $55 \mathrm{mg} / \mathrm{kg}$ b.m., as expected, significantly increased $(p<0.05)$ the rats' blood glucose level over $9 \mathrm{mmol} / \mathrm{L}$, inducing hyperglycaemia in rats. Supplementary $\mathrm{Cr}$ in the form of CrGly administered at a dose of $10 \mathrm{mg} \mathrm{Cr} / \mathrm{kg}$ diet (ca. $0.75 \mathrm{mg} \mathrm{Cr} / \mathrm{kg} \mathrm{b.m.)} \mathrm{restored} \mathrm{the} \mathrm{blood} \mathrm{glucose} \mathrm{level} \mathrm{almost}$ to the healthy rats' level, whereas CrPic only slightly decreased hyperglycaemia in the diabetic rats. The blood insulin levels varied considerably in experimental animals, especially after STZ injection, so no statistical differences were detected between the groups. Also, the calculated insulin resistance index (HOMA-IR) was very scattered in each group. Therefore, there was no significant difference between healthy, Cr-treated and untreated diabetic groups. Chronic hyperglycaemia disorders overall metabolism, especially glucose, lipid, microelement metabolism, as well as in bodily redox balance, which are responsible for further diabetic complications. In the experiment, the diabetic untreated rats had higher blood total cholesterol $(p<0.05)$ and HDL cholesterol
Table 2 Effect of different chromium(III) complexes on overall growth indices in diabetic rats

\begin{tabular}{|c|c|c|c|c|c|}
\hline \multirow{2}{*}{\multicolumn{2}{|c|}{ Index }} & \multicolumn{4}{|l|}{ Experimental group } \\
\hline & & $\mathrm{C}$ & $\mathrm{D}$ & D+CrGly & $\mathrm{D}+\mathrm{CrPic}$ \\
\hline \multicolumn{2}{|c|}{ Food intake (g/day) } & $20.29 \pm 1.05 \mathrm{AB}$ & $22.90 \pm 4.46 \mathrm{~B}$ & $20.05 \pm 0.87 \mathrm{~A}$ & $20.80 \pm 1.46 \mathrm{AB}$ \\
\hline \multicolumn{2}{|c|}{ Fe intake (g/day) } & $0.99 \pm 0.05$ & $1.07 \pm 0.21$ & $0.95 \pm 0.04$ & $1.03 \pm 0.07$ \\
\hline \multicolumn{2}{|c|}{ Zn intake (g/day) } & $0.76 \pm 0.08$ & $0.91 \pm 0.26$ & $0.72 \pm 0.07$ & $0.81 \pm 0.08$ \\
\hline \multicolumn{2}{|c|}{$\mathrm{Cu}$ intake (g/day) } & $0.13 \pm 0.01 \mathrm{AB}$ & $0.15 \pm 0.03 \mathrm{~B}$ & $0.12 \pm 0.01 \mathrm{~A}$ & $0.13 \pm 0.01 \mathrm{AB}$ \\
\hline \multicolumn{2}{|c|}{$\mathrm{Cr}$ intake (g/day) } & $0.027 \pm 0.001 \mathrm{~A}$ & $0.033 \pm 0.006 \mathrm{~A}$ & $0.236 \pm 0.010 \mathrm{~B}$ & $0.248 \pm 0.017 \mathrm{~B}$ \\
\hline \multicolumn{2}{|c|}{$\begin{array}{l}\text { Body mass gain } \\
\quad(\mathrm{g} / 7 \text { weeks })\end{array}$} & $170.40 \pm 26.20$ & $155.00 \pm 35.90$ & $171.22 \pm 10.52$ & $159.11 \pm 26.47$ \\
\hline \multicolumn{2}{|c|}{$\begin{array}{l}\text { Body mass/body length } \\
\text { ratio }(\mathrm{g} / \mathrm{cm})\end{array}$} & $14.35 \pm 0.72$ & $13.49 \pm 0.92$ & $14.06 \pm 0.46$ & $13.61 \pm 1.16$ \\
\hline \multicolumn{2}{|c|}{ FER $(\mathrm{g} / 100 \mathrm{~g}$ feed $)$} & $18.66 \pm 1.87$ & $16.09 \pm 5.93$ & $19.36 \pm 1.51$ & $17.14 \pm 2.97$ \\
\hline \multirow[t]{2}{*}{ Liver } & $(\mathrm{g})$ & $10.89 \pm 0.58$ & $12.02 \pm 2.86$ & $11.34 \pm 1.23$ & $11.72 \pm 1.20$ \\
\hline & (\% b.m.) & $3.08 \pm 0.13$ & $3.38 \pm 0.80$ & $3.19 \pm 0.35$ & $3.29 \pm 0.34$ \\
\hline \multirow[t]{2}{*}{ Kidneys } & $(\mathrm{g})$ & $2.35 \pm 0.16$ & $2.68 \pm 0.58$ & $2.43 \pm 0.21$ & $2.42 \pm 0.24$ \\
\hline & (\% b.m.) & $0.66 \pm 0.05$ & $0.75 \pm 0.16$ & $0.68 \pm 0.06$ & $0.68 \pm 0.07$ \\
\hline \multirow[t]{2}{*}{ Spleen } & $(\mathrm{g})$ & $0.62 \pm 0.05$ & $0.60 \pm 0.08$ & $0.64 \pm 0.04$ & $0.61 \pm 0.05$ \\
\hline & (\% b.m.) & $0.17 \pm 0.02$ & $0.17 \pm 0.02$ & $0.18 \pm 0.01$ & $0.17 \pm 0.01$ \\
\hline \multirow[t]{2}{*}{ Heart } & $(\mathrm{g})$ & $0.97 \pm 0.05$ & $0.91 \pm 0.10$ & $0.99 \pm 0.06$ & $0.95 \pm 0.14$ \\
\hline & (\% b.m.) & $0.27 \pm 0.02$ & $0.26 \pm 0.03$ & $0.28 \pm 0.02$ & $0.27 \pm 0.04$ \\
\hline \multirow[t]{2}{*}{ Testes } & $(\mathrm{g})$ & $3.36 \pm 0.14$ & $3.46 \pm 0.19$ & $3.53 \pm 0.13$ & $3.26 \pm 0.32$ \\
\hline & (\% b.m.) & $0.94 \pm 0.04$ & $0.97 \pm 0.05$ & $0.99 \pm 0.04$ & $0.92 \pm 0.09$ \\
\hline \multirow[t]{2}{*}{ Pancreas } & (g) & $1.09 \pm 0.12$ & $1.12 \pm 0.09$ & $1.06 \pm 0.19$ & $1.16 \pm 0.12$ \\
\hline & (\% b.m.) & $0.31 \pm 0.03$ & $0.31 \pm 0.02$ & $0.30 \pm 0.05$ & $0.33 \pm 0.03$ \\
\hline
\end{tabular}

Data are expressed as mean \pm standard deviation (SD). Values in the row without common uppercase letters differ significantly at $p<0.05$

FER food efficacy ratio, b.m. body mass 
Table 3 Effect of different chromium(III) complex supplementations on serum biochemical indices of diabetic rats

\begin{tabular}{lcccc}
\hline Parameter & \multicolumn{3}{c}{ Experimental group } & \\
\cline { 2 - 5 } & $\mathrm{C}$ & $\mathrm{D}$ & $\mathrm{D}+\mathrm{CrGly}$ & $\mathrm{D}+\mathrm{CrPic}$ \\
\hline Glucose $(\mathrm{mmol} / \mathrm{L})$ & $7.05 \pm 0.30 \mathrm{~A}$ & $9.53 \pm 0.96 \mathrm{~B}$ & $7.53 \pm 0.92 \mathrm{~A}$ & $8.07 \pm 0.94 \mathrm{AB}$ \\
Insulin $(\mu \mathrm{g} / \mathrm{L})$ & $1.82 \pm 0.38$ & $0.96 \pm 0.54$ & $0.62 \pm 0.25$ & $1.52 \pm 1.01$ \\
HOMA-IR index & $2.27 \pm 0.31$ & $1.53 \pm 0.81$ & $0.84 \pm 0.43$ & $2.18 \pm 1.46$ \\
Total cholesterol $(\mathrm{mmol} / \mathrm{L})$ & $2.18 \pm 0.20 \mathrm{~A}$ & $2.56 \pm 0.36 \mathrm{~B}$ & $2.23 \pm 0.28 \mathrm{~A}$ & $2.33 \pm 0.30 \mathrm{AB}$ \\
HDL cholesterol $(\mathrm{mmol} / \mathrm{L})$ & $1.58 \pm 0.10 \mathrm{~A}$ & $1.94 \pm 0.28 \mathrm{~B}$ & $1.66 \pm 0.27 \mathrm{~A}$ & $1.73 \pm 0.24 \mathrm{AB}$ \\
LDL cholesterol $(\mathrm{mmol} / \mathrm{L})$ & $0.21 \pm 0.20$ & $0.31 \pm 0.16$ & $0.25 \pm 0.13$ & $0.20 \pm 0.09$ \\
Triacylglycerols $(\mathrm{mmol} / \mathrm{L})$ & $0.91 \pm 0.16 \mathrm{AB}$ & $1.34 \pm 0.26 \mathrm{~B}$ & $0.85 \pm 0.51 \mathrm{~A}$ & $1.10 \pm 0.50 \mathrm{AB}$ \\
ALT $(\mathrm{U} / \mathrm{L})$ & $16.00 \pm 2.24$ & $22.22 \pm 7.12$ & $18.22 \pm 4.55$ & $18.67 \pm 4.44$ \\
AST $(\mathrm{U} / \mathrm{L})$ & $75.00 \pm 9.63$ & $95.78 \pm 22.21$ & $77.78 \pm 11.95$ & $82.13 \pm 11.17$ \\
Creatinine $(\mu \mathrm{mol} / \mathrm{L})$ & $5.57 \pm 0.74$ & $6.83 \pm 2.77$ & $5.30 \pm 0.49$ & $5.57 \pm 0.88$ \\
Urea $(\mathrm{mmol} / \mathrm{L})$ & $32.20 \pm 4.46$ & $41.00 \pm 16.04$ & $31.78 \pm 2.91$ & $33.44 \pm 5.45$ \\
GST $(\mathrm{nmol} / \mathrm{min})$ & $2.29 \pm 0.74$ & $3.06 \pm 0.39$ & $2.98 \pm 0.31$ & $2.51 \pm 1.14$ \\
TBARS $(\mu \mathrm{M} / \mathrm{L})$ & $27.43 \pm 6.65$ & $34.70 \pm 9.06$ & $27.95 \pm 5.16$ & $33.71 \pm 3.28$ \\
CRP $(\mu \mathrm{g} / \mathrm{L})$ & $0.08 \pm 0.01$ & $0.11 \pm 0.04$ & $0.11 \pm 0.02$ & $0.11 \pm 0.03$ \\
\hline
\end{tabular}

Data are expressed as mean \pm standard deviation. Values in the row without common uppercase letters differ significantly at $p<0.05$

HOMA-IR Homeostasis Model Assessment for Insulin Resistance, ALT alanine aminotransferase activity, AST aspartate aminotransferase activity, GST glutathione $S$-transferase, TBARS thiobarbituric acid reactive substances, $C R P \mathrm{C}$ reactive protein levels and slightly elevated serum triacylglycerols levels. Supplementary CrGly normalized the blood those lipid indices to the level noted in the healthy control rats $(p<0.05)$.

Hyperglycaemia induced by the STZ injection only slightly increased the toxicity indices (ALT activity, AST activity, creatinine and urea), but these changes were not statistically different between the groups. Supplementary $\mathrm{Cr}$ (both CrGly and $\mathrm{CrPic}$ ) did not affect these parameters in blood of rats.

Neither hyperglycaemia or supplementary $\mathrm{Cr}$ (III) complexes had significant influence on serum GST, TBARS and CRP levels.

Table 4 shows the effects of hyperglycaemia and supplementary $\mathrm{Cr}$ on the mineral status in the diabetic rats. In our study, the induction of diabetes with the STZ injection at a relatively low dose did not affect the serum $\mathrm{Fe}, \mathrm{Zn}$ and $\mathrm{Cu}$ levels, but it increased the serum $\mathrm{Cu} / \mathrm{Zn}$ molar ratio by $9.5 \%$. This change was further normalized by supplementary $\mathrm{Cr}$ (both CrGly and CrPic, $10 \mathrm{mg} \mathrm{Cr} / \mathrm{kg}$ of diet, about $0.75 \mathrm{mg}$ $\mathrm{Cr} / \mathrm{kg}$ b.m.).

The liver $\mathrm{Fe}, \mathrm{Zn}$ and $\mathrm{Cu}$ contents were not different in the experimental groups. Also, the liver $\mathrm{Cr}$ levels were not affected by the supplementary $\mathrm{Cr}$. It confirmed earlier observations that this element was poorly accumulated in the liver.

Hyperglycaemia and supplementary $\mathrm{Cr}$ did not change the kidney $\mathrm{Fe}$ contents in rats. By contrast, the liver $\mathrm{Zn}$ level decreased by $20 \%$ in diabetic untreated rats, whereas supplementary $\mathrm{Cr}$ (both $\mathrm{CrGly}$ and $\mathrm{CrPic}$ ) ameliorated these changes in the diabetic rats. The liver $\mathrm{Cu}$ content increased by $135 \%$ in the untreated diabetic group, whereas supplementary $\mathrm{Cr}$ (both CrGly and CrPic) was able to correct this change almost to the level of the healthy control group. Changes in the renal $\mathrm{Zn}$ and $\mathrm{Cu}$ levels brought about shifts in the kidney $\mathrm{Cu} / \mathrm{Zn}$ molar ratio. The index increased by about $200 \%$ in the diabetic group, whereas supplementary $\mathrm{Cr}$ (both forms) corrected this ratio to the level noted in the healthy control group. Neither hyperglycaemia nor supplementary $\mathrm{Cr}$ affected the rats' hepatic and renal $\mathrm{Cr}$ levels.

The heart $\mathrm{Fe}$ and $\mathrm{Cu}$ levels were not statistically different in any of the experimental groups. The heart $\mathrm{Zn}$ content decreased by $15 \%$ in the diabetic untreated rats and supplementary $\mathrm{Cr}$ did not fully correct this shift to the level of the healthy control group. Furthermore, the heart $\mathrm{Cu} / \mathrm{Zn}$ molar ratio increased by $40 \%$ in the hyperglycemic untreated rats. Supplementary $\mathrm{Cr}$ ameliorated this change nearly to the level noted in the healthy control rats.

The spleen $\mathrm{Fe}, \mathrm{Zn}, \mathrm{Cu}$ and $\mathrm{Cr}$ levels were not statistically different in the experimental groups.

Table 5 shows the significant correlation coefficients between serum biochemical indices and tissular mineral levels in diabetic rats. The positive associations were found between serum TBARS and serum insulin $(r=$ $0.576)$, HOMA-IR $(r=0.617)$ and triacylglycerols $(r=$ $0.649)$ levels. The serum glucose correlated with renal $\mathrm{Cu}$ level $(r=0.622)$ and renal $\mathrm{Cu} / \mathrm{Zn}$ ratio $(r=0.575)$, while serum triacylglycerols with splenic Zn level $(r=$ 0.472). 
Table 4 The contents of Fe, $\mathrm{Zn}$ and $\mathrm{Cu}$ in serum and tissues and $\mathrm{Cr}$ in liver and kidney of rats

\begin{tabular}{|c|c|c|c|c|}
\hline \multirow[t]{2}{*}{ Index } & \multicolumn{4}{|l|}{ Experimental group } \\
\hline & $\mathrm{C}$ & $\mathrm{D}$ & D+Cr(III)Gly & $\mathrm{D}+\mathrm{Cr}(\mathrm{III}) \mathrm{Pic}$ \\
\hline \multicolumn{5}{|l|}{ Serum $(\mu \mathrm{mol} / \mathrm{L})$} \\
\hline $\mathrm{Fe}$ & $26.05 \pm 3.91$ & $29.26 \pm 6.80$ & $24.32 \pm 5.25$ & $21.98 \pm 3.58$ \\
\hline $\mathrm{Zn}$ & $18.47 \pm 1.38$ & $18.61 \pm 3.07$ & $18.70 \pm 3.36$ & $18.98 \pm 2.16$ \\
\hline $\mathrm{Cu}$ & $15.49 \pm 0.75$ & $17.11 \pm 2.39$ & $15.80 \pm 1.11$ & $15.09 \pm 1.04$ \\
\hline $\begin{array}{l}\text { Molar } \mathrm{Cu} / \mathrm{Zn} \\
\text { ratio }\end{array}$ & $0.84 \pm 0.08 \mathrm{~A}$ & $0.92 \pm 0.09 \mathrm{~B}$ & $0.79 \pm 0.11 \mathrm{~A}$ & $0.81 \pm 0.12 \mathrm{~A}$ \\
\hline \multicolumn{5}{|c|}{ Liver ( $\mu \mathrm{g} / \mathrm{g}$ d.m.) } \\
\hline $\mathrm{Fe}$ & $215.24 \pm 21.84$ & $257.51 \pm 26.72$ & $277.94 \pm 48.27$ & $248.87 \pm 43.16$ \\
\hline $\mathrm{Zn}$ & $100.71 \pm 17.92$ & $99.63 \pm 10.25$ & $99.53 \pm 11.15$ & $94.99 \pm 9.17$ \\
\hline $\mathrm{Cu}$ & $20.41 \pm 3.08$ & $19.65 \pm 1.90$ & $18.85 \pm 2.25$ & $19.75 \pm 1.53$ \\
\hline $\begin{array}{l}\text { Molar } \mathrm{Cu} / \mathrm{Zn} \\
\text { ratio }\end{array}$ & $0.211 \pm 0.022$ & $0.203 \pm 0.009$ & $0.203 \pm 0.019$ & $0.215 \pm 0.013$ \\
\hline $\mathrm{Cr}$ & $0.761 \pm 0.132$ & $0.663 \pm 0.242$ & $0.727 \pm 0.327$ & $0.734 \pm 0.245$ \\
\hline \multicolumn{5}{|c|}{ Kidney ( $\mu \mathrm{g} / \mathrm{g}$ d.m.) } \\
\hline $\mathrm{Fe}$ & $255.80 \pm 33.10$ & $232.63 \pm 28.52$ & $240.25 \pm 37.61$ & $236.29 \pm 35.86$ \\
\hline $\mathrm{Zn}$ & $112.38 \pm 7.36 \mathrm{~B}$ & $90.18 \pm 20.26 \mathrm{~A}$ & $111.86 \pm 14.11 \mathrm{~B}$ & $108.78 \pm 5.10 \mathrm{~B}$ \\
\hline $\mathrm{Cu}$ & $48.48 \pm 5.80 \mathrm{~A}$ & $113.99 \pm 48.90 \mathrm{~B}$ & $95.24 \pm 6.12 \mathrm{~A}$ & $58.54 \pm 8.54 \mathrm{~A}$ \\
\hline $\begin{array}{l}\text { Molar } \mathrm{Cu} / \mathrm{Zn} \\
\text { ratio }\end{array}$ & $0.427 \pm 0.044 \mathrm{~A}$ & $1.366 \pm 0.750 \mathrm{~B}$ & $0.509 \pm 0.039 \mathrm{~A}$ & $0.555 \pm 0.083 \mathrm{~A}$ \\
\hline $\mathrm{Cr}$ & $0.992 \pm 0.236$ & $0.890 \pm 0.239$ & $0.956 \pm 0.239$ & $0.994 \pm 0.387$ \\
\hline \multicolumn{5}{|c|}{ Heart ( $\mu \mathrm{g} / \mathrm{g}$ d.m.) } \\
\hline $\mathrm{Fe}$ & $318.52 \pm 22.25$ & $321.13 \pm 34.65$ & $313.03 \pm 37.92$ & $310.11 \pm 36.30$ \\
\hline $\mathrm{Zn}$ & $68.79 \pm 6.11 \mathrm{~A}$ & $58.57 \pm 7.15 \mathrm{~A}$ & $61.13 \pm 6.15 \mathrm{AB}$ & $65.42 \pm 11.24 \mathrm{AB}$ \\
\hline $\mathrm{Cu}$ & $20.41 \pm 3.08$ & $19.65 \pm 1.90$ & $18.85 \pm 2.25$ & $19.75 \pm 1.53$ \\
\hline $\begin{array}{l}\text { Molar } \mathrm{Cu} / \mathrm{Zn} \\
\text { ratio }\end{array}$ & $0.338 \pm 0.031 \mathrm{~A}$ & $0.472 \pm 0.079 \mathrm{~B}$ & $0.405 \pm 0.056 \mathrm{~A}$ & $0.345 \pm 0.034 \mathrm{~A}$ \\
\hline \multicolumn{5}{|c|}{ Spleen ( $\mu \mathrm{g} / \mathrm{g}$ d.m.) } \\
\hline $\mathrm{Fe}$ & $2749.55 \pm 472.87$ & $3206.80 \pm 454.50$ & $3083.29 \pm 479.73$ & $3026.95 \pm 461.85$ \\
\hline $\mathrm{Zn}$ & $61.62 \pm 7.87$ & $83.79 \pm 9.14$ & $77.42 \pm 3.77$ & $65.42 \pm 11.24$ \\
\hline $\mathrm{Cu}$ & $48.48 \pm 5.80$ & $113.99 \pm 48.90$ & $95.24 \pm 6.12$ & $58.54 \pm 8.54$ \\
\hline $\begin{array}{l}\text { Molar } \mathrm{Cu} / \mathrm{Zn} \\
\text { ratio }\end{array}$ & $0.267 \pm 0.073$ & $0.257 \pm 0.091$ & $0.226 \pm 0.088$ & $0.258 \pm 0.099$ \\
\hline
\end{tabular}

Data are expressed as mean \pm standard deviation (SD). Values in the row without common uppercase letters differ significantly at $p<0.05$

\section{Discussion}

The first study on the beneficial effect of $\mathrm{Cr}$ (III) on the regulation of carbohydrate metabolism was published in the late 1950s when Schwartz and Mertz et al. [26] found that $\mathrm{Cr}$ (III) appeared to be an essential element in glucose metabolism. Since then, there have been numerous studies on animals [6-8, 27, 28] and humans [29-31], which analysed the role of this element in carbohydrate and lipid metabolism. Many studies on animal-resistant and diabetic animals (mice, rats) showed the therapeutic potential of various supplementary $\mathrm{Cr}$ (III) compounds, which regulated disordered carbohydrate and lipid metabolism in diabetes. On the other hand, clinical trials conducted on healthy and diabetic patients supplemented with various forms of $\mathrm{Cr}$ (both organic and inorganic), given in a wide range of doses and duration, gave highly variable or contradictory results. Yin and Phung [32] reviewed existing reports comprising 14 well-controlled randomized or interventional studies. They concluded that among different $\mathrm{Cr}$ (III) compounds only brewer's yeast $\mathrm{Cr}$ improved fasting plasma glucose levels, but it did not affect the glycated hemoglobin level in DM2 patients. The ineffectiveness of supplementary $\mathrm{Cr}$ in managing diabetes was widely discussed by Costello et al. [33]. According to Vincent [34], the beneficial effect of $\mathrm{Cr}$ (III) supplements on humans was not supported by evidence based research and the discrepancies between animal models and clinical trials resulted from the $\mathrm{Cr}$ dosages used in those trails. Supranutritional or pharmacological dosages were usually applied in studies on animals but they did not correspond to those used by human subjects. Supplementary $\mathrm{Cr}$ (III) 
Table 5 Significant correlations between serum biochemical indices and tissular mineral levels in diabetic rats

\begin{tabular}{lll}
\hline Correlation & \multicolumn{2}{l}{ Pearson's correlation coefficient } \\
\cline { 2 - 3 } & $r$ & $p$ \\
\hline Insulin_TBARS & 0.576 & 0.020 \\
HOMA-IR_TBARS & 0.617 & 0.014 \\
Triacylglycerols_TBARS & 0.649 & 0.009 \\
Glucose-renal Cu & 0.622 & 0.001 \\
Glucose_renal Cu/Zn & 0.575 & 0.004 \\
Triacylglycerols—splenic Zn & 0.472 & 0.017 \\
\hline
\end{tabular}

HOMA-IR Homeostasis Model Assessment for Insulin Resistance, TBARS thiobarbituric acid reactive substances, $p$ probability value for correlation

usually exerts its hypoglycaemic potential only when given in very high dosages ( $>1 \mathrm{mg} \mathrm{Cr} /$ day), but the risk of side effects and toxicity increases considerably.

Diabetes mellitus is a common non-communicable disease with increasing morbidity rates among many populations worldwide. There are different types of diabetes known among humans, but the type 2 diabetes mellitus has the highest prevalence. Researches describe several animal models of insulin resistance and diabetes. One of the most useful and simple method to induce hyperglycaemia in small rodents (mice or rats) relies on pharmacological injection of chemicals, e.g. alloxan or streptozotocin (STZ) that partly destroy pancreatic $\beta$ cell function. According to different authors, depending on the injected dose of STZ, different types of diabetes (type 1 or type 2) can be mimicked in experimental animals. For example, a single injection of STZ to rats at a dose of $>60 \mathrm{mg} / \mathrm{kg} \mathrm{b} . \mathrm{m}$. can lead to drastic destruction of $\beta$ cells; thus, insulin secretion declines resulting in significant chronic hyperglycaemia. In turn, a smaller injected dose of STZ (40-55 $\mathrm{mg} / \mathrm{kg} \mathrm{b.m}$.) and feeding a normal diet leads to the onset of symptoms of type 2 diabetes. This type of diabetes can also be induced by injecting a lower dose of STZ $(35 \mathrm{mg} / \mathrm{kg} \mathrm{b.m}$.) preceded by feeding a high-fat diet.

In our study, the hypoglycemic potential of newly synthesized CrGly and CrPic was compared in tests on rats with "moderate" hyperglycaemia induced by a single injection of STZ (55 mg/kg b.m.). In consequence, the blood glucose level in rats that were administered STZ increased, but the changes were relatively mild, as a consequence of the adding of the mentioned chromium compounds to the diet. Simultaneously, the concentrations of serum insulin levels decreased; total and HDL cholesterol levels and triacylglycerols level increased moderately. During the experiment, supplementary $\mathrm{Cr}$ (10 mg Cr/kg diet, about $0.75 \mathrm{mg} \mathrm{Cr} / \mathrm{kg} \mathrm{b.m}$.) partially ameliorated the disordered glucose metabolism and related lipid indices. The hypoglycaemic effect of CrGly was more pronounced than of $\mathrm{CrPic}$, at the same dietary doses.
The reason for the stronger effect of CrGly is unknown, but it may be caused by better stability, solubility in water (e.g. CrPic is poorly soluble in water), higher rate of intestinal absorption, or other factors. The mechanisms of the $\mathrm{CrPic}$ hyperglycaemia-correcting action have been proposed by various researchers. For example, Chen et al. [35] and Kandadi et al. [36] suggested that the reversal of insulin resistance by CrPic may be mediated by the inhibition of c-Jun NH2-terminal kinase (JNK) activation. Pattar et al. [37] reported that $\mathrm{CrPic}$ can affect cholesterol homeostasis and lower the blood glucose level by altering the plasma membrane composition of cholesterol in fat and muscle cells. CrPic has been shown to enhance glucose transporters (GLUT-4) translocation. Hyperinsulinemia is another aspect that needs to be taken into account when describing factors affecting the CrPic action on cholesterol metabolism. Hoffman et al. [38] found that CrPic improved insulin action in hyperinsulinemia condition and prevented an increase in membrane cholesterol level. This mechanism compromised F-actin integrity, which is necessary for GLUT-4 translocation regulated by insulin.

Vincent [39] concluded that $\mathrm{Cr}$ given at pharmacological doses appeared to increase insulin sensitivity in diabetic and insulin-resistant animals. The mechanism of its action may involve insulin-sensitive movement of $\mathrm{Cr}$ to tissues. This suggests that $\mathrm{Cr}$ could act as a second messenger and transmitting signals from the receptor to target cells.

In our study, CrGly was shown to have the hypoglycemic potential. This compound was previously studied in the Sahin's laboratory [40] using high-fat fed rats. It was found that CrGly supplemented in water at doses of 40 and $80 \mu \mathrm{g} / \mathrm{kg}$ b.m./day decreased the blood glucose/insulin ratio, restored depleted tissue $\mathrm{Cr}$ concentrations and alleviated memory acquisition in insulin-resistant rats.

Chromium in its trivalent form has the potential to affect the status of trace elements due to possibility of its interactions, especially with $\mathrm{Fe}$. It has further consequences, like depression of Fe uptake and deficiency, shift in the redox balance ( $\mathrm{Fe}, \mathrm{Zn}$ and $\mathrm{Cu}$ ), which is disturbed in hyperglycaemia.

$\mathrm{Cr}$ (III) compounds can interact with $\mathrm{Fe}$, as these two elements use the same transport protein-transferrin. They may exhibit competitive activity [41, 42]. Quarles et al. [42] investigated the competitive activity of $\mathrm{Fe}^{+3}, \mathrm{Cr}^{+3}$ and $\mathrm{Ni}^{+2}$ binding to transferrin at different physiological iron/transferrin concentration ratios. These ratios corresponded to different stages of the iron status; normal, iron-deficient, iron-deficient from chronic disease, iron-deficient from inflammation and ironoverload. It was found that the binding of $\mathrm{Cr}^{+3}$ by transferrin was reduced when the amount of $\mathrm{Fe}^{+3}$ was in extreme excess (more than $50 \% \mathrm{Fe}^{+3}$-loaded) [42].

In our study, neither supplementary CrGly nor CrPic (about $0.75 \mathrm{mg} \mathrm{Cr} / \mathrm{kg} \mathrm{b.m}$.) influenced tissular (serum, liver, kidney, heart and spleen) $\mathrm{Fe}$ levels, probably due to relatively low $\mathrm{Cr}$ load. Similarly, the Sahin's team [43] performed a study were 
diabetic rats were supplemented with $\mathrm{Cr}(\mathrm{III})$ histidinate complex (CrHis) at low doses (110 $\mu \mathrm{g} / \mathrm{kg}$ b.m.) for 10 weeks and did not observed significant changes in tissular Fe levels in those animals.

The interaction of $\mathrm{Cr}$ with $\mathrm{Fe}$ in vivo occurs or not, depending on the experimental conditions, mainly on the dose of $\mathrm{Cr}$, duration of treatment and metabolic conditions (health, disease). In our previous trial [6], supplementary $\mathrm{Cr}$ propionate complex (also known as $\mathrm{Cr} 3$ ), given in doses of 1 and $5 \mathrm{mg} / \mathrm{kg}$ b.m. for 8 weeks, decreased the kidney Fe concentration in insulin-resistant rats, whereas in the other trail [27], the same doses of the compound normalized the increased liver Fe content in high-fat diet/STZ injected diabetic rats. Vincent's group [44] also observed a decreased kidney Fe level in obese type 2 diabetic rats supplemented with $1000 \mu \mathrm{g} \mathrm{Cr} / \mathrm{kg} \mathrm{b.m.)} \mathrm{in} \mathrm{the}$ form of $\mathrm{Cr} 3$. In another study, the same team [45] found that $\mathrm{CrPic}$ and $\mathrm{Cr} 3$, given at doses of $1 \mathrm{mg} / \mathrm{kg}$ b.m. for 12 weeks, markedly decreased the hepatic and splenic Fe content but had no influence on the renal and heart levels in obese rats. In a recent study by Staniek and Wójciak [46], supplementary high doses of $\mathrm{Cr} 3$ ( 50 and $500 \mathrm{mg} / \mathrm{kg}$ of diet, ca. 5 and $50 \mathrm{mg} \mathrm{Cr} / \mathrm{kg}$ b.m.) given for 6 weeks did not affect tissular Fe levels in Fedeficient and $\mathrm{Fe}$-adequate healthy female rats.

Earlier studies [47-50] showed that chronic hyperglycaemia in diabetes could disorder the balance of some essential minerals (e.g. $\mathrm{Fe}, \mathrm{Zn}, \mathrm{Cu}, \mathrm{Mg}$ ) and thus worsen overall metabolic processes in the body.

The influence of diabetes on the $\mathrm{Zn}$ status has not been fully elucidated. In some animal trials [43] and clinical studies [51-53], decreased $\mathrm{Zn}$ levels were noticed in tissues and serum/plasma, respectively. The decreased $\mathrm{Zn}$ levels in diabetes may have been caused by disordered intestinal $\mathrm{Zn}$ absorption mechanisms and its increased urinary excretion. On the other hand, some other studies [27, 51] did not report significant changes in $\mathrm{Zn}$ status in the course of diabetes.

In our study, hyperglycaemia significantly decreased the renal $\mathrm{Zn}$ content, while supplementary $\mathrm{Cr}$ (both CrGly and $\mathrm{CrPic}$ ) restored $\mathrm{Zn}$ levels. In our previous study [27], supplementary $\mathrm{Cr} 3$ (about $5 \mathrm{mg} \mathrm{Cr} / \mathrm{kg}$ b.m.) normalized the liver $\mathrm{Zn}$ content in type 2 diabetic rats, but there were no changes in insulin-resistant model of rats $[6,45,48]$.

Hyperglycaemia has been shown can also disturb $\mathrm{Cu}$ status [53-55]. Supplementary $\mathrm{Cr} 3$ in our previous trials, given at doses of $5 \mathrm{mg} \mathrm{Cr} / \mathrm{kg} \mathrm{b.m}$. for 8 weeks, normalized the hepatic $[6,51]$, renal [27] and splenic $\mathrm{Cu}$ contents $[6,51,52]$ in insulin-resistant and diabetic rats.

In our study, both compounds (CrGly and $\mathrm{CrPic}$ ) normalized the serum, renal and cardiac molar $\mathrm{Cu} / \mathrm{Zn}$ ratios and restored the kidney $\mathrm{Zn}$ and $\mathrm{Cu}$ contents. The lowering of the $\mathrm{Cu} /$ $\mathrm{Zn}$ molar ratio may be important due to the prevention of cardiovascular complications in diabetes. Since these two trace elements play an essential role in maintenance of redox balance (as cofactors of SOD), and hyperglycaemia per se affects $\mathrm{Cu}$ and $\mathrm{Zn}$ levels, disturbance in tissular proportion of $\mathrm{Cu}$ to $\mathrm{Zn}$ can further contribute to increasing free radical formation that are responsible for deterioration of tissues and organs as evidenced in diabetic complications [56, 57]. The production of reactive oxygen species (ROS) affects lipids. In diabetes, the level of lipid peroxidation markers such as malondialdehyde and thiobarbituric acid reactive substance (TBARS) increases [57]. Serum higher level of GST in type 2 diabetics was also observed [58]. There was positive relation between the CRP level and glycated hemoglobin observed in an earlier study on diabetics with poor glycaemia control (HbAlc > 9\%) [59]. In this study, we only observed that the serum GST, TBARS and C-reactive protein tended to increase in diabetic rats. One of the weaknesses of this study is lack of tissular oxidative stress biomarkers (e.g. CAT, GPx and other lipid peroxidation indices) and inflammation (e.g. IL-6) that might shed more light on the degree of oxidative damage.

Another important aspect to be addressed in case of supplementary transition elements, here $\mathrm{Cr}$, is the question of safety/ toxicity. In this experiment, supranutritional dosages of $\mathrm{Cr}$ (7-8fold $\mathrm{Cr}$ doses compared to the baseline) were used but did not affect liver enzymes (ALT, AST) values. Supplemented rats had the hepatic and renal $\mathrm{Cr}$ levels comparable with the values of the untreated groups that support previous observations that $\mathrm{Cr} 3+$ ions feature poor gastrointestinal absorption, fast urinary excretion and weak protein-binding affinity.

\section{Conclusions}

Our study confirmed that the $\mathrm{Cr}$ (III) glycinate complex (GrGly) features appreciable hypoglycemic potential in the mild diabetic model of rats. Its effects were even more pronounced than those of chromium(III) picolinate. Apart from that, CrGly did not accumulate in the internal organs and it restored the balance of trace elements $(\mathrm{Zn}, \mathrm{Cu})$ in the diabetic rats.

\section{Compliance with Ethical Standards}

Conflict of Interest The authors declare that they have no conflict of interest.

Ethical approval All procedures performed in studies involving animals were in accordance with the ethical standards of the institution or practice at which the studies were conducted.

Open Access This article is distributed under the terms of the Creative Commons Attribution 4.0 International License (http:// creativecommons.org/licenses/by/4.0/), which permits unrestricted use, distribution, and reproduction in any medium, provided you give appropriate credit to the original author(s) and the source, provide a link to the Creative Commons license, and indicate if changes were made.

Publisher's Note Springer Nature remains neutral with regard to jurisdictional claims in published maps and institutional affiliations. 


\section{References}

1. World Health Organization (WHO) (2016) Global report on diabetes 2016. WHO, Geneva

2. McIver DJ, Grizales AM, Brownstein JS, Goldfine AB (2015) Risk of type 2 diabetes is lower in US adults taking chromiumcontaining supplements. J Nutr 145(12):2675-2682

3. Stoecker B (1999) Chromium absorption, safety, and toxicity. J Trace Elem Exp Med 12:163-169

4. Lamson DS, Plaza SM (2002) The safety and efficacy of high-dose chromium. Altern Med Rev 7(3):218-235

5. Laschinsky N, Kottwitz K, Freund B, Dresow B, Fischer R, Nielsen P (2012) Bioavailability of chromium(III)-supplements in rats and humans. Biometals. 25(5):1051-1060

6. Król E, Krejpcio Z (2010) Chromium(III) propionate complex supplementation improves carbohydrate metabolism in insulinresistance rat model. Food Chem Toxicol 48:2791-2796

7. Sahin K, Tuzcu M, Orhan C, Gencoglu H, Ulas M, Atalay M, Sahin N, Hayirli A, Komorowski JR (2012) The effects of chromium picolinate and chromium histidinate administration on NF- $\mathrm{kB}$ and Nrf2/HO-1 pathway in the brain of diabetic rats. Biol Trace Elem Res 150(1-3):291-296

8. Staniek H, Krejpcio Z, Iwanik K, Szymusiak H, Wieczorek D (2011) Evaluation of the acute oral toxicity class of trinuclear chromium(III) glycinate complex in rat. Biol Trace Elem Res 143(3):1564-1575

9. Feng W, Zhang W, Zhao T, Mao G, Wang W, Wu X, Zhou Z, Huang J, Bao Y, Yang L, Wu X (2015) Evaluation of the reproductive toxicity, glycometabolism, glycometabolism-related enzyme levels and lipid metabolism of chromium malate supplementation in Sprague-Dawley rats. Biol Trace Elem Res 168(1):150-168

10. Peng M, Yang X (2015) Controlling diabetes by chromium complexes: the role of the ligands. J Inorg Biochem 146:97-103

11. Wieczorek D, Zieliński R, Krejpcio Z, Szymusiak H (2005) Identification and purity control of nutritional chromium(III) supplements. In: Zieliński R, Wieczorek D (eds) Current trends in commodity science. Proceedings of the 8th international commodity science conference. The Poznan University of Economics Publishing House, Poznan, pp 1284-1291 (in polish)

12. Wieloch A, Wieczorek D, Staniek H, Szymusiak H, Krejpcio Z, Zieliński R (2007) Tricentric complexes of chromium(III) with glycine and serine ligands. Current Trends in Commodity Science II: 1080-1086 (in polish)

13. Tang HY, Xiao QG, Xu HB, Zhang Y (2015) Hypoglycemic activity and acute oral toxicity of chromium methionine complexes in mice. J Trace Elem Med Biol 29:136-144

14. Mackowiak P, Krejpcio Z, Sassek M, Kaczmarek P, Hertig I, Chmielewska J, Wojciechowicz T, Szczepankiewicz D, Wieczorek D, Szymusiak H, Nowak KW (2010) Evaluation of insulin binding and signaling activity of newly synthesized chromium(III) complexes in vitro. Mol Med Rep 3(2):347-353

15. Reeves PG, Nielsen FH, Fahey GC Jr (1993) AIN-93 purified diets for laboratory rodents: final report of the American Institute of Nutrition ad hoc writing committee on the reformulation of the AIN-76A rodent diet. J Nutr 123:1939-1951

16. Earnshaw A, Figgis BN, Lewis J (1966) Chemistry of polynuclear compounds. Part VI. Magnetic properties of trimeric chromium and iron carboxylates. J Chem Soc A 1656-1663

17. Sacks DB, Bruns DE, Goldstein DE, Maclaren NK, McDonald JM, Parrott M (2002) Guidelines and recommendations for laboratory analysis in the diagnosis and management of diabetes mellitus. Clin Chem 48(3):436-472

18. Miki Y (1999) A homogenous assay for the selective measurement of LDL-cholesterol in serum. Enzymatic selective protection method. Clinical Laboratory 45:398-401
19. Riesen WF (1998) Lipid metabolism. In: Thomas L (ed) Clinical laboratory diagnostics. Use and assessment of clinical laboratory results. TH-Books Verlagssesellschaft, Frankfurt Main, pp 167-169

20. Shephard MD, Whiting MJ (1990) Falsely low estimation of triglycerides in lipemic plasma by the enzymatic triglyceride method with modified Trinder's chromogen. Clin Chem 36:325-329

21. Schumann G, Klauke R (2003) New IFCC reference procedures for the determination of catalytic activity concentrations of five enzymes in serum: preliminary upper reference limits obtained in hospitalized subjects. Clin Chim Acta 327:69-79

22. Newmann DJ, Price CP (1999) Renal function and nitrogen metabolites. In: Burtis CA, Ashwood ER (eds) Tietz book of clinical chemistry. WB Saunders Company, Philadelphia, pp 1239-1242

23. Thomas L (1998) Total protein. In: Thomas L (ed) Clinical laboratory diagnostics. Use and assessment of clinical laboratory results. TH-Books Verlagsgesellschaft, FrankfuntMain, pp 644-647

24. Matthews DR, Hosker JP, Rudenski AS, Naylor BA, Treacher DF, Turner RC (1985) Homeostasis model assessment: insulin resistance and beta-cell function from fasting plasma glucose and insulin concentrations in man. Diabetologia. 28:412-419

25. Cacho J, Sevillano J, de Castro J, Herrera E, Ramos MP (2008) Validation of simple indexes to assess insulin sensitivity during pregnancy in Wistar and Sprague-Dawley rats. Am J Physiol Endocrinol Metab 295:E1269-E1276

26. Schwarz K, Mertz W (1959) Chromium(III) and glucose tolerance factor. Arch Biochem Biophys 85:292-295

27. Król E, Krejpcio Z (2011) Evaluation of anti-diabetic potential of chromium(III) propionate complex in high-fat diet fed and STZ injected rats. Food Chem Toxicol 49(12):3217-3223

28. Ulas M, Orhan C, Tuzcu M, Ozercan IH, Sahin N, Gencoglu H, Komorowski JR, Sahin K (2015) Anti-diabetic potential of chromium histidinate in diabetic retinopathy rats. BMC Complement Altern Med 15:16

29. Król E, Krejpcio Z, Byks H, Bogdański P, Pupek-Musialik D (2011) Effects of chromium brewer's yeast supplementation on body mass, blood carbohydrates, and lipids and minerals in type 2 diabetic patients. Biol Trace Elem Res 143(2):726-737

30. Paiva AN, Lima JG, Medeiros AC, Figueiredo HA, Andrade RL, Ururahy MA, Rezende AA, Brandão-Neto J, Almeida M (2015) Beneficial effects of oral chromium picolinate supplementation on glycemic control in patients with type 2 diabetes: a randomized clinical study. J Trace Elem Med Biol 32:66-72

31. Racek J, Sindberg CD, Moesgaard S, Mainz J, Fabry J, Muller L, Racova K (2013) Effect of chromium-enriched yeast on fasting plasma glucose, glycated haemoglobin and serum lipid levels in patients with type 2 diabetes mellitus treated with insulin. Biol Trace Elem Res 155(1):1-4

32. Yin RV, Phung OJ (2015) Effect of chromium supplementation on glycated hemoglobin and fasting plasma glucose in patients with diabetes mellitus. Nutr J 14:14

33. Costello RB, Dwyer JT, Bailey RL (2016) Chromium supplements for glycemic control in type 2 diabetes: limited evidence of effectiveness. Nutr Rev 74(7):455-468

34. Vincent JB (2017) New evidence against chromium as an essential trace element. J Nutr 147(12):2212-2219

35. Chen G, Liu P, Pattar GR, Tackett L, Bhonagiri P, Strawbridge AB, Elmendorf JS (2006) Chromium activates glucose transporter 4 trafficking and enhances insulin-stimulated glucose transport in 3T3-L1 adipocytes via a cholesterol-dependent mechanism. Mol Endocrinol 20(4):857-870

36. Kandadi MR, Unnikrishnan MK, Warrier AK, Du M, Ren J, Sreejayan N (2011) Chromium (D-phenylalanine) 3 alleviates high fat-induced insulin resistance and lipid abnormalities. J Inorg Biochem 105(1):58-62

37. Pattar GR, Tackett L, Liu P, Elmendorf JS (2006) Chromium picolinate positively influences the glucose transporter system via 
affecting cholesterol homeostasis in adipocytes cultured under hyperglycemic diabetic conditions. Mutat Res 610(1-2):93-100

38. Hoffman NJ, Penque BA, Habegger KM, Sealls W, Tackett L, Elmendorf JS (2014) Chromium enhances insulin responsiveness via AMPK. J Nutr Biochem 25(5):565-572

39. Vincent JB (2015) Is the pharmacological mode of action of chromium(III) as a second messenger? Biol Trace Elem Res 166(1):7-12

40. Sahin K, Tuzcu M, Orhan C, Agca CA, Sahin N, Guvenc M, Krejpcio Z, Staniek H, Hayirli A (2011) The effects of chromium complex and level on glucose metabolism and memory acquisition in rats fed high-fat diet. Biol Trace Elem Res 143(2):1018-1030

41. Quarles CD Jr, Marcus RK, Brumaghim JL (2011) Competitive binding of $\mathrm{Fe} 3+, \mathrm{Cr} 3+$, and $\mathrm{Ni} 2+$ to transferrin. J Biol Inorg Chem 16(6):913-921

42. Quarles CD Jr, Brumaghim JL, Marcus RK (2010) Instrumental comparison of the determination of $\mathrm{Cr}^{3}+$ uptake by human transferrin. Metallomics 2(12):792-799

43. Dogukan A, Sahin N, Tuzcu M, Juturu V, Orhan C, Onderci M, Komorowski J, Sahin K (2009) The effects of chromium histidinate on mineral status of serum and tissue in fat-fed and streptozotocintreated type II diabetic rats. Biol Trace Elem Res 131:124-132

44. Clodfelder BJ, Gullick BM, Lukaski HC, Neggers Y, Vincent JB (2005) Oral administration of the biomimetic $[\mathrm{Cr} 3 \mathrm{O}(\mathrm{O} 2 \mathrm{CCH} 2 \mathrm{CH} 3) 6(\mathrm{H} 2 \mathrm{O}) 3]+$ increases insulin sensitivity and improves blood plasma variables in healthy and type 2 diabetic rats. J Biol Inorg Chem 10:119-130

45. Staniek H, Rhodes NR, Di Bona KR, Deng G, Love ST, Pledger LA, Blount J, Gomberg E, Grappe F, Cernosek C, Peoples B, Rasco JF, Krejpcio Z, Vincent JB (2013) Comparison of tissue metal concentrations in zucker lean, zucker obese, and zucker diabetic fatty rats and the effects of chromium supplementation on tissue metal concentrations. Biol Trace Elem Res 151(3):373-383

46. Staniek H, Wójciak RW (2018) The combined effect of supplementary $\mathrm{Cr}$ (III) propionate complex and iron deficiency on the chromium and iron status in female rats. J Trace Elem Med Biol 45:142149

47. Viktorínováa A, Tošerováb E, Križkob M, Ďuračkováa Z (2009) Altered metabolism of copper, zinc, and magnesium is associated with increased levels of glycated hemoglobin in patients with diabetes mellitus. Metabolism 58:1477-1482
48. Skalnaya MG, Skalny AV, Yurasov VV, Demidov VA, Grabeklis AR, Radysh IV, Tinkov AA (2017) Serum trace elements and electrolytes are associated with fasting plasma glucose and $\mathrm{HbAlc}$ in postmenopausal women with type 2 diabetes mellitus. Biol Trace Elem Res 177(1):25-32

49. Skalnaya MG, Skalny AV, Tinkov AA (2017) Serum copper, zinc, and iron levels, and markers of carbohydrate metabolism in postmenopausal women with prediabetes and type 2 diabetes mellitus. $\mathrm{J}$ Trace Elem Med Biol 43:46-51. https://doi.org/10.1016/j.jtemb. 2016.11.005

50. Presley TD, Duncan AV, Jeffers AB, Fakayode SO (2017) The variation of macro- and micro-minerals of tissues in diabetic and non-diabetic rats. J Trace Elem Med Biol 39:108-115

51. Król E, Krejpcio Z (2013) Dietary chromium(III) propionate complex supplementation affects tissue mineral levels in rats fed highfructose diet. J Elem 18(1):91-98

52. Król E, Krejpcio Z, Iwanik K (2014) Supplementary chromium(III) propionate complex does not protect against insulin resistance in high-fat-fed rats. Biol Trace Elem Res 157(2):147-155

53. Walter RM Jr, Uriu-Hare JY, Olin KL, Oster MH, Anawalt BD, Critchfield JW, Keen CL (1991) Copper, zinc, manganese, and magnesium status and complications of diabetes mellitus. Diabetes Care 14(11):1050-1056

54. Badran M, Morsy R, Soliman H, Elnimr T (2016) Assessment of trace elements levels in patients with type 2 diabetes using multivariate statistical analysis. J Trace Elem Med Biol 33:114-119

55. Krejpcio Z, Wójciak R, Król E (2011) The effect of hyperglycemia on zinc, copper and chromium status in STZ-induced diabetic rats. Trace Elem Electrolytes 28(3):156-161

56. Maritim AC, Sanders RA, Watkins JB III (2003) Diabetes, oxidative stress, and antioxidants: a review. J Biochem Mol Toxicol 17(1):24-38

57. Henriksen EJ, Diamond-Stanic MK, Marchionne EM (2011) Oxidative stress and the etiology of insulin resistance and type 2 diabetes. Free Radic Biol Med 51(5):993-999

58. Sharma M, Gupta S, Singh K, Mehndiratta M, Gautam A, Kalra OP, Shukla R, Gambhir JK (2016) Association of glutathione-Stransferase with patients of type 2 diabetes mellitus with and without nephropathy. Diabetes Metab Syndr 10(4):194-197

59. King DE, Mainous AG 3rd, Buchanan TA, Pearson WS (2003) Creactive protein and glycemic control in adults with diabetes. Diabetes Care 26(5):1535-1539 